\title{
FINANCE AND GROWTH: WHAT WE KNOW AND WHAT WE NEED TO KNOW
}

\author{
By P. Demetriades and S. Andrianova \\ University of Leicester
}

This version: October 19, 2003

\section{Preliminaries}

In modern economies finance underpins virtually every economic transaction that takes place. When we go to the supermarket, we usually pay using credit or debit cards issued by commercial banks (or the supermarkets themselves). Even when we pay using cash, we have to first find an ATM in order to withdraw the necessary bank notes. The banking system, which includes commercial banks as well as the central bank (the Bank of England in the UK), provides the payments system which makes economic exchange possible. It is hard to imagine what economies would look like without 'money'-broadly defined as anything that is used in exchange for goods and services and the settlement of debt. Besides providing the means of payment, which underpins all economic transactions, the financial system provides a link between current and future output and consumption. When we borrow from a bank to buy a car, we are essentially bringing forward consumption against future income. This is made possible because financial intermediaries, like banks, raise funds from surplus units (those economic agents whose income is greater than their current expenditure) and pass them on as loans to deficit units (those economic agents whose income is less than their current expenditure). Without the financial system, which facilitates such inter-temporal transfer of resources, all consumption would have to be financed from current income. Similarly, firms would not be able to raise capital to finance investment in plant and equipment unless they already had accumulated enough profits in previous years. Many profitable, socially beneficial, investment opportunities - for example, the creation of new firms and innovationwould simply not take place.

Since the financial system is at the core of modern economies, the proposition that finance is essential for economic growth - the change in output from one year to the next - is therefore in some sense almost a trivial one. It may therefore come as a surprise to non-economists that there is a very large and growing body of academic literature that discusses the (seemingly rather obvious) relationship between finance and growth. However, there are very good reasons why this literature exists, other 
than career progression of many academics! The main reason can be traced back to pre-1970s economics literature, which, by and large, takes finance for granted. Traditional 'neoclassical' economics, taught in most mainstream microeconomics courses throughout the world, does not explicitly address the role of finance in consumption or investment decisions. It implicitly assumes that finance is 'neutral'; that is to say it does not make any difference whatsoever to economic decision making. ${ }^{1}$

Neoclassical consumer and producer theory analyses consumption and investment decisions without explicit reference to finance. In static models of consumption (i.e. models where time is not explicitly analysed), households choose the bundle of goods and services that maximises their utility subject to a single-period income constraint, without any explicit reference to the payments system. Similarly, in this type of models, firms maximise profit by choosing the optimal level of inputs and output, again without any explicit reference to money or finance. By their very nature, such models are not capable of addressing the role of money and finance, since money and finance are both linked to inter-temporal decision-making. However, even when inter-temporal models are used to analyse consumption and investment decisions over time, the traditional neoclassical approach has been to treat money and finance in a superficial manner, usually by assuming - often implicitly - that there is a 'perfect capital market', in which economic agents can borrow or lend as much as they wish to maximise their respective objective functions. In practice, this assumption translates into having a single interest rate that is used to discount to the present all future income or expenditure streams. In the neoclassical theory of investment, the source of finance does not matter in determining the level of investment; bank loans, bonds, retained earnings, stock issues all have the same cost. ${ }^{2}$ Similarly, neoclassical consumer theory assumes that households face no borrowing constraints, i.e. they can borrow or lend as much as they like at the same interest rate. We all, of course, know that there are hundreds of different interest rates on the market, when we wish to borrow (or lend), and that searching to find the best rate does take time. Sometimes when we think we have found the best rate, we fill in all the necessary application forms, the lender may well decide to decline the application. Meanwhile, we have incurred substantial transaction costs in terms of both the fees we may have paid and the time we have wasted. This is, of course, a rather superficial criticism of neoclassical consumer theory. The conclusions of the model may not be fundamentally altered even if we explicitly allow for transaction costs - thus to ignore them may be an acceptable simplification. A more fundamental criticism is that allocation decisions themselves may change when we relax the assumption of perfect capital markets. If a consumer is refused credit, then her consumption decision may well change - she may not buy the car she intended to,

\footnotetext{
${ }^{1}$ Principal-agent approach and incomplete contracts (for a recent survey, see Hart (2001)), which fall outside of the fold of neoclassical economics but within the 'theory of the firm' part of modern economics, help explain why the Modigliani-Miller neutrality result is invalidated in reality.

${ }^{2}$ This is sometimes known as the 'Modigliani-Miller' theorem, which states that the capital structure of the firm is irrelevant.
} 
which, has implications for the firm that produces cars. Similarly, if a firm cannot raise capital, an investment opportunity may go unexploited. Or it may be exploited by a competitor in a different country, so that even if the firm was to 'save-up' to carry out this investment, by the time it is able to do so, the project may no longer be profitable. Thus, finance may well 'matter' in a very fundamental sense. This can have profound implications, not only in terms of explaining why some countries grow faster than others but also in terms of the validity of some of the most fundamental axioms of mainstream (neoclassical) economics, on which many generations of economic students have been educated. For example, the so-called 'First Theorem of Welfare Economics', which states that the 'competitive economy is Pareto-efficient' (that is to say no one could be made better off without making someone else worse off), is derived from a model that has no role for money and no role for finance. ${ }^{3}$

Once we relax the assumption of 'perfect capital markets', many interesting questions arise, including what the sources and implications of financial market imperfections might be. We have already touched on one imperfection, namely 'transaction costs'. We have also touched upon what may be at the root of transaction costs when we said that it takes time for consumers to find out about the various interest rates on the market. The key to understanding finance - banks, capital markets, money, prudential regulation of financial markets and institutions - is indeed the understanding of the information problems that are associated with financial decision making by firms, households and financial institutions. In the last 30 years or so, a very large body of academic literature has emerged on the economics of information, much of which specifically focuses on finance. Take, for example, the information problems associated with borrowing and lending decisions. Information is usually distributed asymmetrically (shared unequally) between borrowers and lenders. This gives rise to two problems: adverse selection and moral hazard. Adverse selection occurs before a transaction takes place and in the case of loans it refers to the selection of bad credit risks. ${ }^{4}$ Moral hazard occurs after a loan is granted and refers to the incentive of the borrower to act in a way that is not acceptable to the lender (if they knew about it), typically taking on excessive risk since this increases the probability of default. Between them, adverse selection and moral hazard can explain much of what we see in the financial system and can also provide a justification for some forms of government intervention, such as prudential regulation and supervision of financial institutions. They can also explain why banks exist in the first place. In a nutshell, banks can be efficient forms of organisation able to address the adverse selection and moral hazard problems in the credit market, mainly through

\footnotetext{
${ }^{3}$ The first theorem of welfare economics is the 20th century analogue of Adam Smith's 'invisible hand': the notion that free markets will achieve a socially optimal outcome if left to their own devices.

${ }^{4}$ This literature can be traced back to Akerlof's analysis of the 'lemons' problem in the second hand car market (1970). Akerlof showed that the market can collapse as a result of adverse selection. One of the most important earlier applications to finance is the paper by Stiglitz and Weiss (1981), which explains how adverse selection in the credit market can result in arbitrary rationing of credit among identical borrowers.
} 
screening and monitoring of potential borrowers. Information problems are also at the heart of theoretical models that try to explain the relationship between finance and growth (e.g. Bencivenga and Smith (2000)).

Once it is accepted that what goes on in (imperfect) financial markets can make a difference to economic decision making and, consequently, to the allocation of resources, then an in-depth study of various aspects of the relationship between finance and growth begins to make a lot of sense. Different types of finance, by addressing information problems in different ways, can result in differences in both the volume and pattern of investment (e.g. those with short-term payoffs versus those with long-term payoffs), as well as the productivity of physical and human capital. In any sensible economic model, these are important channels of economic growth. Additionally, it also becomes legitimate to study government policies towards the financial system: should, for example, governments own banks, should they provide central banking services, should they control capital flows or even interest rates, should they stipulate capital or reserve requirements for banks, should they regulate stock markets, and, if so, how, etc. Since information problems are at the heart of financial decision making, it is also not unreasonable to argue that the relationship between finance and growth may in part depend on how successfully the financial system manages to address information problems. An economy with a well-functioning financial system that manages to address the variety of adverse selection and moral hazard problems adequately, is likely to enjoy high rates of investment, and to have a highly productive capital stock. In contrast, an economy with a financial system that fails to effectively address information problems is likely to exhibit high levels of uncertainty, low and unproductive investment and low growth, as well as financial instability.

In order to unravel what we know about the relationship between finance and growth and highlight areas where we need to know more, we will embark on a selective (and somewhat idiosyncratic) review of relevant academic, mainly empirical, literature. We will focus particularly on policy issues, importantly financial liberalisation, government ownership of banks and prudential regulation. As we shall see, this literature is not free from controversy, indeed one could argue it is full of contentious issues! This should perhaps not be surprising. We are dealing with an area of economics where policy issues are abundant (e.g. financial liberalisation, financial globalisation), and where a lot is at stake, in both developed and developing countries. We will certainly attempt to provide an objective assessment of various points of view. However, it is left to the reader to decide the extent to which we succeed in doing so.

The paper is structured as follows. Section 2 provides a review of mainly empirical literature on the finance-growth nexus, which draws on a number of influential cross-country studies, as well as on a variety of studies that focus on individual countries through time. Section 3 discusses likely obstacles to financial development, including financial repression, government ownership of banks, legal factors and political economy constraints. Finally, section 4 summarises and concludes. 


\section{The Empirical Relationship between Finance and Growth}

As already argued, in modern market economies the financial system underpins virtually all economic transactions. A positive association between measures of financial sector development and economic growth (or real GDP) is, therefore, a very basic first test of the finance-growth relationship. Indeed, this question has preoccupied the empirical literature on finance and growth for quite some time. The main conclusion that has emerged on this question by early as well as more recent studies is that there is indeed an association in the data both across countries and within countries, over time, even though the relationship is neither linear nor very precise. $^{5}$

The more contentious issue in this literature has been not whether this positive association exists in the data but what is the direction of causality between these two variables. Specifically, does financial development cause economic growth or does it simply follow growth generated elsewhere in the economy? Applied economists approach causality-type questions using the notion of 'Granger causality', which utilises the concept of statistical predictability. If variable $X$ helps predict the future time path of variable $Y$, then it is said that $X$ Granger-causes $Y$. Without getting too philosophical, this is of course not quite the same as true causality: if a variable helps predict another variable it does not necessarily mean it causes it. It may well be the case that there is another variable, $Z$, that is the true cause of both $Y$ and $X$, but $X$ responds more quickly to $Z$ than $Y$. Hence Granger-causality may just mean that $X$ is a leading indicator of $Y$. Thus, even if we find that financial development helps predict future economic growth (in the Granger-sense), it does not necessarily follow that it causes it. However, this need not concern us too much, for the following reason. Conceptually, financial development is, at best, a facilitator of economic growth, rather than its ultimate true cause. Its true cause has to be sought in the real sector: the creation of new ideas, the discovery of natural resources or of alternative ways of using existing resources, product innovation, technological progress etc. Finance is, of course, essential in ensuring that new ideas are translated into new products and services, natural resources are exploited, and that new products and technologies materialise. A well-functioning financial system is one that enables the real economy to fully exploit such new opportunities. Thus, we could interpret Granger-causality from financial development to economic growth as a basic second test that a healthy, well-functioning, financial system must normally be able to pass.

What if we don't find Granger-causality running from financial development to economic growth but we find reverse causality, i.e. from economic growth to financial development? This is usually pretty bad news, assuming of course we

\footnotetext{
${ }^{5}$ See Fry (1995) for an extensive survey of earlier literature. There are, however, important exceptions, e.g., De Gregorio and Guidotti (1995), on which see below.
} 
trust our econometric procedures and data (for example, we are confident that the variables we have used to measure financial development are the appropriate ones - more on this below). Financial development is, of course, expected to follow economic growth elsewhere under most circumstances, since when the real economy grows, there should be more savings coming into the financial system, which will allow it to extend new loans etc. But it is also expected to lead economic growth, assuming a well-functioning financial system. Thus, we would normally expect to see bi-directional causality between finance and growth, sometimes known technically as a feedback relationship.

If there is no Granger causality from finance to growth, a number of factors could be at play. One possibility is that funds are being diverted to non-productive activities due to micro-economic inefficiencies in the banking system. If the banks are not able to solve informational problems very well, because the problems themselves are either very severe or because their screening and monitoring systems are not effective, they may end up financing low quality projects or may avoid funding long-term projects altogether, focusing on projects with shorter-term payoffs. An alternative explanation is political interference in the banking system that may channel funds into unproductive projects (e.g. building weapons of mass destruction or financing white elephant projects that generate rents for government officials). Reverse causality may also indicate fundamental macroeconomic problems, such as a high degree of political or economic uncertainty, including high and unpredictable inflation. ${ }^{6}$ Under these circumstances, financial savings may not be channelled into new investment because firms, domestic and foreign, are simply not willing to invest when the future is highly uncertain. Thus, a country's financial savings might be channelled into foreign banks and may well end up financing growth in other countries. A final, related but more innocuous, explanation of reverse causality, is that the financial system under consideration is either an international or a regional centre of finance, and may therefore have a weak relationship with domestic economic growth (e.g. Hong Kong, London, or New York).

One of the most influential papers in recent literature that examines the relationship between financial development and economic growth is King and Levine (1993). Utilising data on 77 countries for the period 1960-89, King and Levine consider a variety of indicators of financial development, mostly ratios of aggregates measuring the size of the financial system relative to GDP, and 3 growth indicators (average growth rate of real GDP per capita, average growth rate of capital stock per capita and a measure of total factor productivity). They estimate a cross-country growth regression of the form:

$$
g_{i}=a+b F D_{i}+c Z_{i}+u_{i},
$$

where $g_{i}$ is the growth rate of country $i$ averaged over the period 1960-1989, $F D_{i}$ is the level of financial development of country $i, Z_{i}$ is a vector of other possible deter-

\footnotetext{
${ }^{6}$ Rousseau and Wachtel (2001), for example, report that in high inflation countries the effect of finance on growth weakens.
} 
minants of economic growth, such as initial income, education, inflation, openness to trade, political uncertainty etc, and $u_{i}$ is a statistical error term.

They find that the coefficient of DEPTH (the indicator of $F D$ defined as the ratio of liquid liabilities to GDP in the equation above), is 2.4 and highly significant statistically. In his recent review of the literature on finance and growth, Levine (2003) suggests that raising DEPTH from the mean of the slowest growing quartile of countries to the mean of the fastest growing quartile, would have increased growth by almost 1 percent per year. Over a 30-year period, this is a lot of growth! Levine, does, however, admit that these calculations ignore causality and the issue of how to increase DEPTH. In another set of regressions, King and Levine replace $F D$ by its level in 1960, in an attempt to isolate the causal influence of financial development on economic growth. The effect remains positive and significant, which allows the authors to conclude that financial development helps predict long-run growth.

There are a number of problems with the interpretation of the King and Levine (1993) results, some of which Levine (2003) alludes to, including the difficulty in establishing causality in cross-country data sets and the measures of financial development utilised. Additionally, when dealing with cross-country data sets, one is, at best, dealing with the average effects of financial development. This is fine, assuming the relationship does not vary considerably across countries. However, if it is driven by one or two 'outliers' - not uncommon in cross-country growth regressions - these results would be meaningless for non-outlier countries from a policy perspective. Moreover, it is frequently the case that these results are sensitive to the specification of the equation; changing the control variables, $Z$, could well affect the statistical significance of $b$, making any results difficult to interpret. These problems led a number of authors to examine the finance-growth relationship using time-series data on individual countries. Time-series data allow the use of appropriate statistical procedures, such as cointegration, to test for the existence of long-run relationships; they also allow the use of statistical procedures that can shed light on the causality between two or more variables in both the long-run and the short-run. Their main limitation, however, is that the time-series that we have at our disposal are not sufficiently long to allow a very high degree of confidence in the estimates. ${ }^{7}$ Demetriades and Hussein (1996), is one of the earlier studies in recent literature that adopts the time-series approach for a reasonably large and diverse set of countries. These authors use data from 16 countries that were not highly developed in 1960, for the period 1960-1990. They find a stable long-run relationship between indicators of financial development and real per capita GDP in 14 countries. However, the direction of causality varies considerably across countries. Alarmingly, while they find bi-directional causality in seven countries, they find clear evidence of

\footnotetext{
${ }^{7}$ Ideally, one would need at least 100 years of data to carry out such tests with a high degree of confidence. However, such data are available for very few countries and, even then, because of changing statistical procedures may not be strictly comparable across time. It is nonetheless now possible to use quarterly data for many developing countries for 25 years or more, which means that samples could exceed 100 observations, increasing the reliability of estimates.
} 
reverse causality in six cases (El Salvador, Greece, Pakistan, Portugal, South Africa and Turkey). Odedokun (1996) also reports different effects of finance on growth in different countries. Even more disturbing results are found by De Gregorio and Guidotti (1995), who report a negative relationship between financial development and growth in twelve Latin American countries during 1950-1985.

Thus, according to time-series studies, one-size does not seem to fit all in the case of the finance-growth relationship. Rioja and Valev (forthcoming) examine this issue more closely using panel techniques and data from 74 countries and suggest that there are three distinct regions of financial development. The effects of financial development on growth vary across the three. In the low region, which mostly contains very poor countries, increases in financial development have no statistically significant effect on growth. In the intermediate region, financial development changes are most effective in promoting growth. In the high region, additional financial development has positive, albeit smaller effects.

Many of the empirical studies on the finance-growth nexus have utilised indicators that are primarily focused on the development of the banking system, such as the ratio of liquid liabilities or private credit to GDP. More recently, there has been an explosion of studies that use broader measures of financial development, particularly those including the development of stock markets. This is partly justified by the growth of stock markets around the world, particularly in emerging market economies, which makes any study of the finance-growth nexus incomplete if it does not consider the contribution to growth that stock markets might have. Efficient stock markets, like well-functioning banking systems, could play a complementary role in financing investment to that of banks, and may also help to exercise corporate control through mergers and acquisitions. If stock markets are (informationally) efficient, i.e. stock prices truly reflect the expected future profitability of companies, resources flow to the most efficient and productive companies, which are then able to implement their investment plans. On the other hand, if stock prices are excessively volatile and are prone to speculation, bubbles, and price manipulation, then stock markets may be unable to contribute to growth or may even have negative effects by compounding economic uncertainty (Singh 1997).

Some studies using cross-country growth regressions find that stock markets have large positive effects on growth, in addition to banks (Levine and Zervos 1998). However, the causality issue is difficult to address in these studies. Moreover, it is now known that some of these results are driven by outliers; excluding the East Asian 'tigers' from the sample, alters the nature of the results substantially. ${ }^{8}$

For these reasons, a number of authors have resorted to time-series methods, even though this means that fewer countries can be examined. Arestis, Demetriades and

\footnotetext{
${ }^{8} \mathrm{Zhu}$, Ash and Pollin (2002) show that the Levine-Zervos results are driven by the 'East-Asian tigers': once these countries are excluded from the sample or their influence is controlled statistically, the main result that stock market liquidity is positively associated with long-run economic growth becomes statistically insignificant.
} 
Luintel (2001), henceforth ADL, is one such study. These authors utilise time-series data and methods to examine the causality between stock markets, banks and real GDP. Because time-series techniques are data intensive, data limitations dictate that they focus on five advanced countries: UK, US, Germany, France and Japan. ADL find a relatively strong long-run relationship between the three variables in Germany, France and Japan, where they find that stock markets have made a significant contribution to growth in addition to banks, albeit of a much smaller magnitude (ranging from $1 / 3$ to $1 / 7$ of that of banks). Interestingly, they also find that the link between financial development and growth in the UK and the US is statistically weak and, if anything, exhibits reverse causality. ADL suggest that their results are consistent with the view that bank-based financial systems, such as those of Germany and Japan, may be better able to promote long-run economic growth than capital-market based ones. They acknowledge, however, that the results may to some extent reflect the international character of the UK and the US financial systems, which may well result in a weaker relationship between domestic GDP and their respective, internationally oriented, financial systems.

Beck and Levine (forthcoming) utilise panel data techniques, which exploit both the cross-section and time-series variation in data, to examine the role of stock markets alongside that of banks on economic growth. Their data set includes 40 countries over 1975-1998. They find that stock market liquidity (the total value of shares traded relative to market capitalisation), is positively related to subsequent GDP growth. In their regressions, they control for banking sector development using a credit-based measure, which is also found to have a positive, larger, influence. Once again, their estimated coefficients suggest that the influence of both banks and stock markets on growth is quite large. However, while panel data techniques offer a very good way to increase sample sizes and to exploit data variation, they may suffer from other limitations. For instance, averaging over 5-years per country, as Beck and Levine do, is unlikely to be sufficient to remove business-cycle influences from the data. This means that the estimated relationships may not capture the underlying long-run relationships very well and may well suffer from econometric problems, including dynamic heterogeneity, ${ }^{9}$ resulting in biased estimates (Pesaran and Smith 1995).

Thus, it is still difficult to draw out any reliable policy implications from crosscountry or panel regressions, and those conclusions that we may draw from timeseries studies for individual countries cannot easily be generalised. With increasing data availability it may be possible to utilise panels that use observations that have been averaged over 10 years instead of 5 , which is clearly preferable. Confidence in the results obtained from time-series studies will also increase, once we are able to have samples that span 40 or even 50 years, especially if these data are available in quarterly frequencies. There is, therefore, considerable scope for further work in this area, especially in order to increase the degree of confidence in the results that

\footnotetext{
${ }^{9}$ Broadly speaking, dynamic heterogeneity refers to a situation in which different countries exhibit different business cycle characteristics, such as different speeds of adjustment to shocks.
} 
we already have or, indeed, to check their robustness.

To summarise, there is now a voluminous empirical literature on the relationship between financial development and economic growth, using different methodologies, different data sets, and a variety of indicators, which this section has briefly and selectively reviewed. What we do know from this literature is that there is, with few exceptions, a positive long-run association between financial development and economic growth, as measured either by the long-run growth rate or the level of per capita GDP. What we are less sure about is the causal nature of the estimated relationships between growth and finance. We need to have a lot more results, using larger data sets and better econometric methods, before we can conclude with a reasonable degree of confidence that finance leads economic growth in every country in the world. Meanwhile, results indicating reverse causality need not be dismissed, just because they do not agree with the 'one-size fits all' approach. These results could be very useful for policy makers (domestic and international), since they may suggest some underlying structural problems such as political interference in the financial system, cronyism, corruption, political uncertainty, etc. A final conclusion that we would like to draw is that, irrespective of the direction of causality between finance and growth found in empirical studies, a better understanding of the factors that promote financial development - in a broader sense than perhaps may be suggested by various indicators - is likely to shed light on the mechanisms and policies that may promote economic growth. Even in the cases where we observe reverse causality in the data, promoting financial development in the sense of identifying and fixing what is wrong in the financial system, is likely to result in more growth, even if it doesn't necessarily lead to higher values of the financial development indicators. There should therefore be little doubt that better, if not more, finance is likely to result in more growth.

\section{Promoting Financial Development}

In understanding what factors may promote financial development, it is instructive to ask an almost equivalent question: what are the obstacles to financial development, where it has not occurred? To this end, we review relevant literature under the following four themes: (i) financial repression and liberalisation, (ii) government ownership of banks, (iii) legal factors, and (iv) political economy constraints.

\subsection{Financial Repression and Liberalisation}

The early literature on financial development (McKinnon 1973, Shaw 1973), highlights ill-conceived government interventions, like interest rate ceilings, high reserve requirements and directed credit programmes, as the main source of financial underdevelopment. These controls were dubbed 'financial repression'. Controls on capital flows have also frequently been included among such interventions, even though a 
growing number of authors (Arestis and Demetriades 1999, Stiglitz 2000) now acknowledge that these may occasionally have a stabilising influence.

McKinnon and Shaw argued that ceilings on deposit and/or lending rates, because of high inflation rates, frequently resulted in negative real rates of interest, which discouraged saving and created an excess demand for investable funds. The volume of investment declined when real interest rates were too low and so did the productivity of capital, since when real interest rates are low, low-productivity investment projects may become profitable. The problem was frequently exacerbated by governments that interfered in credit allocation, which aimed at allocating credit to 'priority sectors', frequently a euphemism for cronyism and corruption. In addition, governments imposed excessively high reserve requirements on banks, usually at low or even zero interest rates, in order to finance their own deficits cheaply. These reserve requirements, however, acted as a tax on the banking system, resulting in further depression of deposit rates, thereby creating greater disincentives for financial saving. Removing interest rate ceilings, reducing reserve requirements and abolishing priority lending - freeing the domestic financial system from such government distortions - was seen as critical in delivering financial development and, consequently more growth. For a time, this became the mantra of the IMF and the World Bank, whose officials prescribed (and frequently imposed) financial liberalisation to many developing countries.

The reality of financial liberalisation in the 1970s and early 1980s, was, however, very different from what was predicted by the financial repression literature. Real interest rates soared to unprecedented levels (sometimes in excess of $+20 \%$ ), as a result of fierce competition for funds and excessive risk-taking by firms and banks themselves. Speculation flourished and when borrowers were unable to pay their debts, many banks failed and governments were forced to (re-)nationalise them, resulting in very large fiscal costs. Instead of more growth, there was more unemployment. Instead of more prosperity there was more poverty. Instead of a better, more developed, financial system there were failed banks that had to be rescued by the government. In a classic paper entitled "Good-Bye Financial Repression, Hello Financial Crash", Diaz-Alejandro (1985) provides a first attempt at analysing the failure of financial liberalisation in Latin America. Subsequent analysis of what went wrong in the first wave of financial reforms (Villanueva and Mirakhor 1990) highlights adverse preconditions, such as macroeconomic instability (large fiscal deficits and high inflation), exacerbated moral hazard problems and inadequacies in banking supervision. McKinnon (1991) suggests that incorrect sequencing of reforms was at the root of the problem. He suggests that financial liberalisation should be preceded by real sector reforms, including privatisation of state enterprises, aimed at ensuring that relative prices adequately reflect economic scarcities. He also advocates reducing deficits and inflation before embarking on reforms, to remove any price distortions that may be associated with high inflation. Finally, adequate regulation and supervision of banks is necessary in order to contain moral hazard problems in the banking system. McKinnon also argues that domestic financial liberalisation (i.e. interest rate deregulation and lowering of reserve requirements) should precede 
liberalisation of capital flows, with restrictions on long-term flows, such as FDI, being lifted first while those on volatile short-term flows being lifted last.

Adverse selection and moral hazard problems are exacerbated in the aftermath of interest rate liberalisation, especially when banks are not sufficiently well capitalised. Under-capitalised banks have incentives to take excessive risks, especially if they are protected by government safety nets (deposit insurance or 'too big to fail' policies). It is often believed that such safety nets encourage banks to behave imprudently, since they allow them to benefit from a one-way (unfair) bet against the government. By making speculative loans at very high interest rates they stand to make very large profits, assuming of course that the borrowers do not default. If the borrowers do default, the bank will not suffer the full cost of these defaults if it is bailed out by the government. Even if the bank is allowed to fail, the depositors may not suffer if they are protected by deposit insurance. Thus, depositors have no incentives to monitor bank managers when they are protected by deposit insurance. Bank shareholders have no incentive to monitor bank managers either when they don't have much capital at stake. In the extreme, bank shareholders may even benefit from gambling behaviour by the managers, if they have little or no capital at stake (i.e. when the bank has little or no net worth). In such circumstances it may be in their interests to instruct bank managers to gamble (with taxpayer's money) - this is sometimes known as 'gambling for resurrection' (Llewellyn 1999).

A number of papers provide empirical evidence that substantiates the uncanny relationship between financial liberalisation and financial crises. Demirgüç-Kunt and Detragiache (1999) analyse the determinants of the probability of banking crises in 53 countries during 1980-95. They find that financial liberalisation has a very large and statistically significant positive effect on the probability of banking crisis, even after controlling for many other possible determinants of banking crises. The magnitudes are quite startling: the probability of a banking crisis increases up to 5 times following financial liberalisation. The increase in this probability is lower in more developed economies or when institutional quality is high. Their institutional quality indicators include law and order, bureaucratic delay, contract enforcement, quality of bureaucracy and corruption. The authors argue that the influence of financial liberalisation on financial fragility works its way through reduced bank franchise values. Financial liberalisation intensifies competition, which reduces the value of a banking license to shareholders and exacerbates moral hazard in the form of excessively risky lending. They also present evidence which suggests that while financial liberalisation has a positive effect on financial development, banking crises have a negative effect. They find that the two effects offset each other in countries that liberalise from a position of positive real interest rates, while in those that started from a repressed position the effect of financial liberalisation on financial development outweighs that of the banking crisis. They conclude by arguing in favour of gradual financial liberalisation, to be accompanied or preceded by institutional development.

Kaminsky and Reinhart (1999) in their empirical analysis of the 'twin'-banking 
and currency - crises find that financial liberalisation and/or increased access to international capital markets have played a major role in the first phase of such crises. Specifically, they examine the empirical regularities and the sources of 76 currency crises and 26 banking crises. They find that banking and currency crises are closely linked in the aftermath of financial liberalisation, with banking crises beginning before currencies collapse. Currency collapse exacerbates the problems in the banking system further, making the 'twin crises' a lot more severe than crises that occur in isolation. Financial liberalisation or increased access to international capital markets fuel the boom phase of the boom-bust cycle that precedes crises. This phase is associated with increased access to financing and the formation of asset price bubbles. The bust is attributed to overvalued exchange rates, declining exports, and a rising cost of credit, both of which create vulnerabilities in the financial system. The authors see the draconian reductions in reserve requirements that accompany financial liberalisation as one of the main factors that trigger lending booms. They also suggest that high interest rates result in increased risk taking, in line with earlier literature. The authors conclude by arguing that there is a compelling case for strengthening banking regulation and supervision to 'allow countries to sail smoothly through the perilous waters of financial liberalization'. And that the Asian crisis of 1997-98, like earlier crises 'remind us that capital inflows can on occasion be too much of a good thing' (p. 496).

Stiglitz (2000) offers further insights into the Asian financial crisis of 1997-98, as well as on other recent crises, including Russia and Latin America, drawing on his experience as Chief Economist of the World Bank. He suggests that premature financial and capital market liberalisation -in the sense of not first putting in place an effective regulatory framework - was at the root of these crises. He also suggests that global economic arrangements are fundamentally weak. Stiglitz's analysis highlights some of the difficulties that the sequencing literature has in explaining the East Asian crisis, which ensued soon after these countries liberalised their financial systems. By conventional definitions, these countries had good economic policies and sound financial institutions. They did not have fiscal deficits, they enjoyed very high growth rates for long periods and their inflation rates were low. Their macroeconomic fundamentals were (or at least appeared to be) very strong. They were also thought to have reasonably respectable systems of banking regulation and supervision (World Bank 1993). Stiglitz emphasises the destabilising influence of short-term capital flows in his analysis, arguing that 'there is not only no case for capital market liberalization, [ ] there is a fairly compelling case against full liberalization' (p. 1076). His analysis of why capital market liberalisation produces instability, not growth, identifies the following fallacy in the pro-liberalisation arguments, namely that 'financial and capital markets are essentially different from markets for ordinary good and services'. He points out that capital and financial markets are 'information-gathering' markets, which means that standard results for competitive markets derived from models with perfect information are not applicable. He also argues that capital flows are pro-cyclical, therefore the argument that the opening of capital markets would allow diversification and enhance stability is 
deficient. Finally, he challenges the notion that any destabilising effects emanating from capital account liberalisation are transitory, while the benefits are permanent, by alluding to a vast econometric literature, ${ }^{10}$ which suggests that shocks to output can be long-lasting. The debate has now shifted, Stiglitz argues, to the type of interventions that might be necessary in order to stabilise short-term capital flows, rather than their desirability as such, with these actions being endorsed by the IMF itself.

Stiglitz (1999) elaborates on the weaknesses of the institutional financial architecture, which amplify the destabilising effects of financial liberalisation. Specifically, he highlights the role of the tight monetary policies recommended by the IMF to Asian crisis countries, in the aftermath of the crisis. These policies, which were aimed at stabilising exchange rates, had the opposite effect, Stiglitz argues. This was because high interest rates raised the probability of corporate bankruptcies. This, in turn, made international lenders more reluctant to renew or rollover their loans to highly leveraged East Asian corporations. This highly contentious issue was for a time at the centre of a major argument between Joseph Stiglitz and his counterpart at the IMF, Stanley Fischer. There have been several attempts to address this question, many of these from World Bank and IMF economists. These have resulted in two different sides of the argument. However, a major empirical issue that needs to be tackled when addressing this question is that in any reasonable economic model interest rates and exchange rates are simultaneously determined. Hence, identifying the effects of policy tightening is extremely difficult. Caporale, Cipollini and Demetriades (forthcoming) exploit the heteroskedasticity properties in the relevant time-series for these variables in order to identify the system. Using a bivariate vector autoregression model (VECM), they find that while tight monetary policy helped to defend the currencies concerned during tranquil periods, it had the opposite effect during the Asian crisis.

A number of authors continue, however, to propagate the benefits of financial liberalisation, focusing primarily on the effects of capital account liberalisation on stock returns and the cost of equity capital, using event studies. Bekaert and Harvey (2000), for example, measure how (capital account) liberalisation has affected the equity return-generating process in 20 emerging markets. They use a variety of methods to determine liberalisation dates, including official liberalisation dates, dates of first issues of country funds or American Depository Receipts (ADRs), which may signal a change in access to international capital markets, and econometric methods to identify structural breaks in the series. They find that dividend yields decline after liberalisations, but the effect is always less than $1 \%$ on average. They also find that there is no significant impact of liberalisation on unconditional volatility. In a series of other studies (see Bekaert and Harvey (2003) for a review), they challenge Stiglitz's critique of capital account liberalisation, dubbing as 'odd' the whole discussion concerning increased volatility. They review evidence which suggests that the ratio of investment to GDP increases following liberalisation, while

\footnotetext{
${ }^{10}$ For a flavour of this literature, known as "unit root literature", see, for example, Durlauf (1989).
} 
the ratio of consumption to GDP does not increase. Durham (2000), however, finds that many of the results in this literature are sensitive to (i) alternative liberalisation event dates and (ii) conditioning on other determinants of stock returns suggested by the literature on stock market anomalies.

Evidence from time-series studies on the effects of financial liberalisation on financial development is mixed. While it is quite common to find that the real interest rate has a small positive effect on financial development, there is also evidence to suggest that the direct effects of 'repressive' policies on financial development are sometimes positive and quite large. Demetriades and Luintel (2001) provide time-series evidence from South Korea - one of the fastest growing economies in the world - in which an index of financial repression is found to have a large positive effect on financial development. They explain this finding by arguing that the Korean banking system behaved like a cartel when interest rates were deregulated. Using a monopoly-bank model they show that mild repression of lending rates increases the amount of financial intermediation. ${ }^{11}$ It is also worth noting that domestic financial liberalisation in South Korea was not followed by financial instability. The Korean crisis occurred well after domestic interest rates were liberalised; it followed the opening up of short-term capital flows, which destabilised the banking system. In sharp contrast to their findings on South Korea in an earlier study of the Indian banking system, Demetriades and Luintel (1997) find that financial repression had large negative effects on financial development, over and above the retarding influence of low real rates of interest. The difference in results is attributed as reflecting institutional differences and differences in the severity of repression. While mild financial repression may turn out to have positive effects under certain conditions, severe financial repression is likely to result in financial under-development not only due to large negative real interest rates, but also because of other disincentive effects.

The conclusion that we wish to draw from the above discussion is that the case for financial liberalisation promoting financial development and growth is far from proven. More often than not, financial liberalisation has been associated with severe bouts of financial and economic instability. Moreover, this association is not coincidental, it is well documented in the empirical literature and there are sound theoretical reasons to expect it, emanating from financial market imperfections. These imperfections and associated moral hazard problems can, nonetheless, be contained by a sound institutional infrastructure. An effective system of financial regulation and supervision would ensure that banks have adequate risk management systems and that bank shareholders are penalised if banks take excessive risks. Capital requirements that accurately reflect risk-taking by banks are one mechanism for achieving this. Increased transparency regarding banks' risk management systems, as well as increased disclosure concerning exposure to large risks, can help to in-

\footnotetext{
${ }^{11}$ An alternative explanation why 'repressive' policies, such as deposit rate ceilings, may appear to have a positive effect on financial development is that they may help to reduce moral hazard behaviour by banks, which may in turn reduce the riskiness of bank deposits. See, for example, Arestis and Demetriades (1997) or Hellmann, Murdock and Stiglitz (2000).
} 
crease market discipline on bank managers and may well contain such risk taking. Institutions such as contract enforcement and the rule-of-law also matter, since they have implications for the protection of investors' property rights, ${ }^{12}$ which are crucial in determining investor confidence in the financial system, as well as for the effective implementation of financial regulation and supervision.

\subsection{Government Ownership of Banks}

Another form of government intervention in the financial system that may have implications for financial development and growth, and the one that has attracted considerable attention in recent literature, is government ownership of banks. Government owned (henceforth 'state') banks provide an effective means for politicians to influence the allocation of credit, allowing them to support firms and enterprises that may further their political interests. This view, known as the 'political view of state banks', has a clear policy implication: privatising state banks can improve the efficiency of credit allocation and, consequently, can have positive effects on the quality and quantity of investment. Privatisation of government-owned banks is also likely to promote financial development, since private banks would be in a better position to attract funds into the banking system than inefficient state-owned banks.

La Porta, Lopez-de-Silanes and Shleifer (2002) examine the relationship between government ownership of banks, financial development and economic growth using a cross-country data set. They find that government ownership of banks is negatively correlated with both financial development and growth. The estimated coefficients are quite large: they suggest that a $10 \%$ reduction in the share of banking assets owned by the government is associated with an increase in growth by $0.25 \%$ per annum. Assuming that the relationships are causal, the clear policy implication is that the privatisation of government owned banks would yield very large benefits in terms of additional financial development and economic growth. La Porta et al. also report bi-variate regressions that suggest that government ownership of banks is higher when institutional indicators, including property rights and government efficiency, are weak. This highlights the possibility of reverse causation: if government ownership of banks is the result of institutional weaknesses, then lower growth rates and financial under-development may be the result of the same institutional weaknesses. Thus, privatising state banks without addressing the institutional deficiencies that brought them about may not have the positive effects of growth predicted by La Porta et al. (2002).

Andrianova, Demetriades and Shortland (2003), henceforth ADS, provide further insights into the relationship between institutions, state banks and financial

\footnotetext{
${ }^{12}$ Knack and Keefer (1995), Mauro (1995), Svensson (1998), and Acemoglu, Johnson and Robinson (2001) provide macroeconomic evidence that suggests a negative impact of insecure property rights on economic growth and investment. Using survey data from transition economies, Johnson, McMillan and Woodruff (2002) find that weak property rights dominate limited access to external finance as a constraint on entrepreneurs' investment decisions.
} 
development using a locational model of banking in which there are two types of private banks - 'honest' and 'opportunistic' - and a state bank. Private banks are assumed to offer more competitive interest rates to depositors than the state bank. In the absence of deposit-contract enforcement problems they are therefore always preferred by depositors. However, if deposit contract enforcement is weak and the number of opportunistic banks is large, then some depositors would prefer to place their savings in the state bank, which offers a risk-free, albeit lower, rate of return. ADS derive three types of equilibria in their model: (i) a 'high' equilibrium, in which institutions are strong, only private banks exist and opportunistic banks honour their contract; (ii) an 'intermediate' equilibrium in which private banks and the state bank co-exist, in which opportunistic banks find it profitable to breach their deposit contracts, because of relatively weaker contract enforcement and (iii) a 'low' equilibrium, in which only the state bank exists, because contract enforcement is weak and the proportion of opportunistic banks is high. They show that in the intermediate region the proportion of state bank deposits declines when institutional quality increases. They also show that privatisation of the state bank in the low equilibrium region results in financial disintermediation (i.e. no private bank would emerge to fill the gap, as depositors will not trust it). ADS extend their model to allow for politically motivated subsidies to the state bank. They show that the higher the level of these subsidies, the smaller the 'high' equilibrium region. Thus, state banks may feature in equilibrium, even when there are no enforcement problems, because they are able to offer more competitive deposit rates than some private banks. ADS also provide a variety of empirical tests of the relationships predicted by their model, using data from 83 countries. They find that institutional quality indicators, including financial regulation, rule of law and disclosure rules, are much more strongly and robustly correlated to the share of state banks than proxies for politically-driven subsidies. They conclude that the privatisation of state banks is, at best, unnecessary, since it is better to build institutions that foster the development of private banks and remove subsidies from state banks. At worse it is detrimental, since when institutions are weak it will almost certainly lead to financial disintermediation.

\subsection{Legal Factors}

La Porta, Lopez-de-Silanes and Shleifer (1998), henceforth LLS, examine legal rules covering the protection of (minority) shareholders and creditors, and the quality of their enforcement in 49 countries. They draw on the work of comparative legal scholars, who classify national legal systems into major families of law, even though national differences remain within the same families. These scholars identify two broad legal traditions: civil law and common law. The civil law tradition, which is the oldest and most influential, originates in Roman law. It relies heavily on legal scholars to ascertain and formulate rules, statutes and comprehensive codes, as a primary means of settling disputes. Within the civil law tradition, there are three common families of laws: French, German and Scandinavian. The French 
Commercial code was written in 1807 and was 'exported' by Napoleon's armies to other countries in central Europe; eventually it was also exported to French colonies in Africa, Asia and the Caribbean. The German Commercial Code, written in 1897, had an influence in central and eastern Europe, Japan, Korea and Taiwan. The Scandinavian family, considered less a derivative of Roman law than French and German law, is considered sufficiently distinct from the other families by legal scholars, but has no influence outside the Nordic countries. The common law family, which originates in the law of England, is formed by judges in the resolution of specific disputes. Precedents from judicial decisions, not contributions by scholars, form the basis of common law. Common law has spread to the former British colonies, including the US, Canada, Australia, India, South Africa, Nigeria, Kenya, Ireland, Hong-Kong etc. LLS find that common-law countries generally have the strongest shareholder protection, while civil-law countries have the weakest. Within the civil law group, French civil law countries offer the worst legal protection to shareholders. Similar results are found for the protection of creditors. French civil law countries compensate for weak investor protection, through mandatory dividend to shareholders and legal reserves. LLS also find that legal origins have a significant influence on legal enforcement, with common law countries and Scandinavian civil law countries having the best quality of law enforcement while French civil law countries having the worst. They do, however, find that the main determinant of legal enforcement is GDP per capita: richer countries have higher quality of law enforcement. Thus, rich countries within the French civil law group, such as France and Belgium, could well offer better law enforcement than poor common law countries.

La Porta, Lopez-de-Silanes, Shleifer and Vishny (1997) examine the influence of legal origins on financial development, mainly focusing on the development of capital markets. They use the same sample of 49 countries as La Porta et al. (1998) and find that French civil law countries have the least developed capital markets, especially as compared to common law countries. Their indicators of financial development include: stock market capitalisation/GNP, number of firms relative to population size, initial public offerings (IPOs) relative to population and debt/GDP. Their empirical findings suggest that civil law countries have lower levels of capital market development than common law countries. However, there are no significant differences in relation to banking sector development. In the regressions that use debt/GDP as the dependent variable, once the authors control for creditor rights, only the Scandinavian civil law dummy is negative and statistically significant at conventional levels.

What could be concluded from La Porta et al. (1997, 1998) is that civil-law countries, which seem to offer less legal protection to minority shareholders and creditors, have less developed capital markets and greater concentration of ownership at both industry and firm level. However, the implications of legal origins for the development of the banking system, which is perhaps the most important part of the financial system for many developing countries, are less clear cut. Indeed, Rajan and Zingales (forthcoming) find that French civil code countries were no less financially 
developed in 1913 and 1929 than common law countries, and only started to lag behind after World War II. Moreover, legal traditions may themselves be determined by historical, cultural, socio-economic and political factors, so it is not easy to draw out any policy implications from these results. Legal origins are, in fact, highly correlated with a number of other institutional quality indicators, including the efficiency of the judiciary, bureaucratic quality, generalised level of trust etc, so it is difficult to disentangle the effects of legal origins on financial development from those of other institutions (Zingales 2003). Finally, even if we were to accept that it is the legal system that determines financial development and ultimately growth, there remains the question of how to transform a legal system from the supposedly inferior French Civil Code to the supposedly superior Common Law one. There are, therefore, many unanswered questions as regards the relationship between law and finance, offering fertile ground for more research.

\subsection{Political Economy Factors}

In the light of the previous discussion of the positive relationship between finance and growth, it is, perhaps, surprising that some countries appear unable or unwilling to harness financial development. It may be plausible to conjecture that efficiency considerations - for example, limited scope for scale economies necessary for efficiency of financial markets - may preclude or slow down the development of financial markets in poorer countries. However, the retarded growth of the financial sector, or, indeed, the variability of the level of financial development in industrialised nations at the same stage of economic development, as documented in an important paper by Rajan and Zingales (forthcoming), remains a puzzle. ${ }^{13}$ The key to solving this puzzle, according to Rajan and Zingales, is the lack of political will, or capture of politicians by interest groups opposed to financial openness. In other words, financial development comes about only if the ruling elite welcomes it.

The economic argument constructed by Rajan and Zingales in support of this conjecture proceeds as follows. Openness to either international trade or international capital, while beneficial for the country's welfare in stimulating the development of its financial and product markets, breeds competition and thus threatens the rents of incumbents. When financial markets are under-developed, two types of incumbents enjoy rents and therefore may oppose openness and financial development. Established industrial firms, or 'industrial incumbents', are in a privileged position when obtaining external finance due to their reputational capital and their ability to provide collateral. Their rents are generated because new firms with profitable business projects have to team up with an industrial incumbent in order to obtain financing. 'Financial incumbents', in turn, capitalise on their informational advantage which stems from relation-based financing, and become monopolists in providing loans to firms when problems of poor disclosure and weak contract enforce-

\footnotetext{
${ }^{13}$ Rajan and Zingales (forthcoming) find that 'by most measures, countries were more financially developed in 1913 than in 1980 and only recently have they surpassed their 1913 levels'.
} 
ment raise fixed costs of new financial entrants. Financial development improves transparency and enforcement thus reducing the barriers to entry and undermining not just the profits of incumbents who have to operate in a more competitive environment, but the source of their rents since entrants are able to effectively operate without any help from incumbents. Despite the benefits it brings (after all, better disclosure rules improve operating conditions for all - existing and new-firms), financial development threatens both the profits and the positional rents of the incumbents.

The way to remove incumbents' opposition to financial development, Rajan and Zingales argue, is to simultaneously open product and capital markets. More intense competition from foreign entrants, following liberalisation of either trade or capital flows alone, will only intensify incumbents' opposition to financial development. For example, trade liberalisation under protected capital markets would reduce industrial incumbents' competitiveness and profits and thus increase their demand for cheaper and larger loans to defend their domestic market position. Their opposition to financial development-which, if comes about, would further undermine incumbents' competitiveness, this time vis-à-vis the domestic entrants - would now be even stronger. Incumbent financiers' resistance to financial development, when capital markets are protected while product markets are liberalised, is likely to remain the same: after all, relation-based financing favours dealing with existing large clients and these are incumbent industrialists. Similarly, protected product markets in combination with free international capital flows, create a stronger resistance to financial development from the incumbent financiers (who are forced now to compete for their best and largest industrial clients with foreign financial institutions) while leaving industrial incumbents' incentives for financial development unchanged (there is little use in additional external finance available from tapping international capital markets when the economy is closed to trade). In contrast, trade liberalisation accompanied by freeing of capital flows, forces the incumbent industrialists and financiers to make the best of the liberalised markets in order to cope with the competitive pressure from foreign and domestic entrants. Lower profits of the industrial incumbents and their greater need for external finance now force them to explore possibilities of tapping the international capital markets. If unsuccessful, these industrialists would in fact now support financial innovations that aid greater transparency and thus improve their own access to domestic finance. Incumbent financiers, being forced to lose some of their best clients to foreign competition and at the same time to accept lower profitability of their remaining clientele, are now forced to seek new lending opportunities among young industrial firms which are less known and possibly more risky. Financing these new firms is likely to be unattractive to foreign financiers, but would create incentives for domestic incumbent financiers to support the improvements in, and development of, domestic financial markets. In sum, trade and capital liberalisation aligns the interests of industrial and financial incumbents with those of the rest of the economy and financial development becomes possible.

The empirical evidence provided by Rajan and Zingales focuses on a variety of 
relationships which suggest that the combination of trade and capital openness are, indeed, correlated with greater financial development. Their findings, while consistent with their conceptual arguments, provide, at best, indirect evidence about the importance played by interest-group politics in financial development. Moreover, their sample of countries, driven by data availability in the pre-World War II period, is rather limited and in some of the regressions the sample size is as low as 17 observations. Thus, while the ideas in Rajan and Zingales (forthcoming) by themselves undoubtedly advance our understanding of political economy factors, the empirical evidence that is provided is less convincing, which clearly leaves ample scope for further empirical research. Further questions that need to be addressed, both theoretically and empirically, include the following. How do special interest groups come into existence? What institutions and policies-'political pre-conditions' for institutions and financial development-moderate the influence of interest groups? If the most effective way to curb incumbents' opposition to financial development is by means of increased openness and competitiveness, then what is the best combination of policies that could pave the way for rapid institutional development? What is the role of the state for shaping the institutional infrastructure in a way that limits the power of the interest groups and the scope for capture of the government policies by special interests? These are all exciting questions that await researchers' attention.

\subsection{Concluding Remarks}

It is now widely acknowledged that institutions have a first-order effect on financial development and growth, and that the strength of these institutions may determine the success or failure of policies like bank privatisation and financial liberalisation. Financial regulation, the legal system and related institutions, by enhancing investor confidence, play a key role in the functioning of financial markets and institutions, and seem, therefore, to hold the key to both financial development and economic growth. The critical issue, now at the frontier of the literature, is to advance our understanding of the obstacles to financial development, including institutional, legal and political economy constraints. There is no doubt that, while we now know a lot more about financial development than we did even ten years ago, pushing the frontier further will require new and imaginative, possibly trans-disciplinary, approaches. 


\section{References}

Acemoglu, D., S. Johnson, and J. Robinson, "The Colonial Origins of Comparative Development: An Empirical Investigation," American Economic Review, 2001, 91 (5), 1369-1401.

Akerlof, G., "The Market for 'Lemons': Quality Uncertainty and the Market Mechanism," Quarterly Journal of Economics, 1970, 84, 488-500.

Andrianova, S., P. O. Demetriades, and A. Shortland, "State Banks, Institutions and Financial Development," 2003. Paper presented at European Economic Association Conference, Stockholm.

Arestis, P. and P. O. Demetriades, "Financial Development and Economic Growth: Assessing the Evidence," Economic Journal, May 1997, 107, 783-799.

— and _ , "Financial Liberalization: The Experience of Developing Economies," Eastern Economic Journal, 1999, 25 (4), 441-57.

_ , _ _ and K. B. Luintel, "Financial Development and Economic Growth: The Role of Stock Markets," Journal of Money, Credit, and Banking, 2001, 33 (1), 16-41.

Beck, T. and R. Levine, "Stock Markets, Banks, and Growth: Panel Evidence," Journal of Banking and Finance, forthcoming.

Bekaert, G. and C. Harvey, "Foreign Speculators and Emerging Equity Markets," Journal of Finance, 2000, 55, 565-614.

and ___ , "Emerging Markets Finance," Journal of Empirical Finance, 2003, $10,3-55$.

Bencivenga, V. R. and B. D. Smith, "Financial Intermediation and Endogenous Growth," Review of Economic Studies, 2000, 58, 195-209.

Caporale, G. M., A. Cipollini, and P. O. Demetriades, "Monetary Policy and the Exchange Rate During the Asian Crisis: Identification through Heteroskedasticity," Journal of International Money and Finance, forthcoming.

De Gregorio, J. and P. Guidotti, "Financial Development and Economic Growth," World Development, 1995, 23 (3), 433-48.

Demetriades, P. O. and K. B. Luintel, "The Direct Costs of Financial Repression: Evidence from India," Review of Economics and Statistics, 1997, 79 (2), $311-20$.

_ and _ _ "Financial Restraints in the South Korean Miracle," Journal of Development Economics, 2001, 64 (2), 459-79. 
and K. Hussein, "Does Financial Development Cause Economic Growth? Time-series Evidence from 16 Countries," Journal of Development Economics, 1996, 51, 387-411.

Demirgüç-Kunt, A. and E. Detragiache, "Financial Liberalization and Financial Fragility," in B. Pleskovic and J. Stiglitz, eds., Annual World Bank Conference on Development Economics 1998., Washington DC: World Bank: Reuters, Pearson Education, 1999, pp. 303-31.

Diaz-Alejandro, C., "Good-Bye Financial Repression, Hello Financial Crash," Journal of Development Economics, 1985, 19 (1), 1-24.

Durham, J. B., "Emerging Stock Market Liberalization, Total Returns, and Real Effects: Some Sensitivity Analyses," 2000. Queen Elizabeth House, University of Oxford, Working paper No. 48.

Durlauf, S., "Output Persistence, Economic Structure, and the Choice of Stabilization Policy," Brookings Papers on Economic Activity, 1989, 2, 69-137.

Fry, M. J., Money, Interest and Banking in Economic Development, Baltimore: Johns Hopkins University Press, 1995. 2nd edition.

Hart, O., "Financial Contracting," Journal of Economic Literature, 2001, 39 (4).

Hellmann, T. F., K. C. Murdock, and J. E. Stiglitz, "Liberalization, Moral Hazard in Banking, and Prudential Regulation: Are Capital Requirements Enough?," American Economic Review, 2000, 90 (1), 147-65.

Johnson, S., J. McMillan, and C. Woodruff, "Property Rights and Finance," American Economic Review, 2002, 92 (5), 1335-56.

Kaminsky, G. L. and C. M. Reinhart, "The Twin Crises: the Causes of Banking and Balance-of-Payments Problems," American Economic Review, 1999, 89 (3), 473-500.

King, R. G. and R. Levine, "Finance and Growth: Schumpeter Might be Right," Quarterly Journal of Economics, 1993, 108, 717-37.

Knack, S. and P. Keefer, "Institutions and Economic Performance," Economics and Politics, 1995, 7 (3), 207-28.

La Porta, R., F. Lopez-de-Silanes, A. Shleifer, and R. Vishny, "Legal Determinants of External Finance," Journal of Finance, 1997, 52, 1131-50.

_ _ _ _ and __ , "Law and Finance," Journal of Political Economy, 1998, $106(6), 1113-55$.

, and __ , "Government Ownership of Banks," Journal of Finance, 2002, 57 (1), 265-301. 
Levine, R., "More on Finance and Growth: More Finance, More Growth?," Federal Reserve Bank of St. Louis Review, 2003, 85 (4), 31-46.

and S. Zervos, "Stock Markets, Banks and Economic Growth," American Economic Review, 1998, 88, 537-58.

Llewellyn, D., "The Economic Rationale for Financial Regulation," 1999. Financial Services Authority Occasional Paper \# 1.

Mauro, P., "Corruption and Growth," Quarterly Journal of Economics, 1995, 110 (3), 681-712.

McKinnon, R. I., Money and Capital in Economic Development, Washington DC: Brookings Institution, 1973.

- The Order of Economic Liberalization: Financial Control in the Transition to a Market Economy, Baltimore: Johns Hopkins University Press, 1991.

Odedokun, M. O., "Alternative Econometric Approaches for Analyzing the Role of the Financial Sector in Economic Growth: Time Series Evidence from LDC's," Journal of Development Economics, 1996, 50 (1), 119-46.

Pesaran, M. H. and R. P. Smith, "Estimating Long-run Relationships from Dynamic Heterogeneous Panels," Journal of Econometrics, 1995, 68, 79-113.

Rajan, R. and L. Zingales, "The Great Reversals: The Politics of Financial Development in the 20th Century," Journal of Financial Economics, forthcoming.

Rioja, F. and N. Valev, "Does One Size Fit All?: A Re-examination of the Finance and Growth Relationship," Journal of Development Economics, forthcoming.

Rousseau, P. L. and P. Wachtel, "Inflation, Financial Development and Growth," in T. Negishi, R. Ramachandran, and K. Mino, eds., Economic Theory, Dynamics and Markets: Essays in Honor of Ryuzo Sato, Boston: Kluwer, 2001, pp. 309-24.

Shaw, E. S., Financial Deepening in Economic Development, New York: Oxford University Press, 1973.

Singh, A., "Stock Markets, Financial Liberalisation and Economic Development," Economic Journal, 1997, 10\%, 771-82.

Stiglitz, J., "Interest Rates, Risk, and Imperfect Markets: Puzzles and Policies," Oxford Review of Economic Policy, 1999, 15 (2), 59-76.

, "Capital Market Liberalization, Economic Growth and Instability," World Development, 2000, 28 (6), 1075-86.

and A. Weiss, "Credit Rationing in Markets with Imperfect Information," American Economic Review, 1981, 71 (3), 393-410. 
Svensson, J., "Investment, Property Rights and Political Instability," European Economic Review, 1998, 42 (7), 1317-42.

Villanueva, D. and A. Mirakhor, "Strategies for Financial Reforms: Interest Rate Policies, Stabilization, and Bank Supervision in Developing Countries," IMF Staff Papers, 1990, 37 (3), 509-36.

World Bank, The East Asian Miracle, Oxford: Oxford University Press, 1993.

Zhu, A., M. Ash, and R. Pollin, "Stock Market Liquidity and Economic Growth: A Critical Appraisal of the Levine-Zervos Model," 2002. University of Massachusetts at Amherst, Political Economy Research Institute, Working Paper \# 47.

Zingales, L., "The Weak Links," Federal Reserve Bank of St. Louis Review, 2003, $85(4), 47-52$. 